\title{
A Comparison of Soil Carbon Stocks of Intact and Restored Mangrove Forests in Northern Vietnam
}

\author{
Pham Hong Tinh ${ }^{1, *}$, Nguyen Thi Hong Hanh ${ }^{1}$, Vo Van Thanh ${ }^{2}$, Mai Sy Tuan ${ }^{2}$, \\ Pham Van Quang ${ }^{3}$, Sahadev Sharma ${ }^{4}$ and Richard A. MacKenzie ${ }^{5}$ (D) \\ 1 Faculty of Environment, Hanoi University of Natural Resources and Environment, Hanoi 10000, Vietnam; \\ nthhanh.mt@hunre.edu.vn \\ 2 Mangrove Ecosystem Research Center, Hanoi National University of Education, Hanoi 10000, Vietnam; \\ vothanhlong93@gmail.com (V.V.T.); tuanms@hnue.edu.vn (M.S.T.) \\ 3 Faculty of Environmental Sciences, VNU University of Sciences, Vietnam National University, Hanoi 10000, \\ Vietnam; phamvanquang@vnu.edu.vn \\ 4 Institute of Ocean and Earth Sciences, University of Malaya, Kuala Lumpur 50603, Malaysia; \\ ssharma@um.edu.my \\ 5 USDA Forest Service, Pacific Southwest Research Station, Institute of Pacific Islands Forestry, Hilo, HI 96721, \\ USA; richard.mackenzie@usda.gov \\ * Correspondence: phtinh@hunre.edu.vn; Tel.: +84-983-708-199
}

Received: 13 May 2020; Accepted: 8 June 2020; Published: 10 June 2020

check for updates

\begin{abstract}
Background and Objectives: In northern Vietnam, nearly 37,100 hectares of mangroves were lost from 1964-1997 due to unsustainable harvest and deforestation for the creation of shrimp aquaculture ponds. To offset these losses, efforts in the late 1990s have resulted in thousands of hectares of mangroves being restored, but few studies to date have examined how effective these efforts are at creating restored mangrove forests that function similarly to the intact mangroves they are intended to replace. Materials and Methods: We quantified and compared soil carbon (C) stocks among restored (mono and mixed species) and intact mangrove forests in the provinces of Quang Ninh, Thai Binh, Nam Dinh and Thanh Hoa in northern Vietnam. A total of 96 soil cores up to a depth of $200 \mathrm{~cm}$ were collected every $25 \mathrm{~m}(25,50,75,100,125$, and $150 \mathrm{~m})$ along 16 linear transects that were $150 \mathrm{~m}$ long and perpendicular to the mangrove upland interface (six cores along each transect) at Quang Ninh (four transects), Thai Binh (five), Nam Dinh (four) and Thanh Hoa (three). Five-cm-long soil samples were then collected from the $0-15 \mathrm{~cm}, 15-30 \mathrm{~cm}, 30-50 \mathrm{~cm}, 50-100 \mathrm{~cm}$, and $>100 \mathrm{~cm}$ depth intervals of each soil core. Results: The study confirmed that the soil C stock of 20-25-year-old restored mangrove forest $(217.74 \pm 16.82 \mathrm{Mg} / \mathrm{ha})$ was not significantly different from that of intact mangrove forest $(300.68 \pm 51.61 \mathrm{Mg} / \mathrm{ha})(p>0.05)$. Soil C stocks of Quang Ninh $(323.89 \pm 28.43 \mathrm{Mg} / \mathrm{ha})$ were not significantly different from Nam Dinh $(249.81 \pm 19.09 \mathrm{Mg} / \mathrm{ha})$, but both of those were significantly larger than Thai Binh $(201.42 \pm 27.65 \mathrm{Mg} / \mathrm{ha})$ and Thanh Hoa $(178.98 \pm 30.82 \mathrm{Mg} / \mathrm{ha})(p<0.05)$. Soil C stock differences among provinces could be due to their different geomorphological characteristics and mangrove age. Soil $\mathrm{C}$ stocks did not differ among mangroves that were restored with mixed mangrove species ( $289.75 \pm 33.28 \mathrm{Mg} / \mathrm{ha})$, Sonneratia caseolaris (L.) Engl. $(255.67 \pm 13.11 \mathrm{Mg} / \mathrm{ha})$ or Aegiceras corniculatum (L.) Blanco ( $278.15 \pm 43.86 \mathrm{Mg} / \mathrm{ha})$, but soil C stocks of those mangroves were significantly greater than that of Kandelia obovata Sheue, Liu \& Yong $(174.04 \pm 20.38 \mathrm{Mg} / \mathrm{ha})(p<0.05)$. Conclusion: There were significant differences in the soil $\mathrm{C}$ stocks of mangrove forests among species and provinces in northern Vietnam. The soil C stock of 20-25-year-old restored mangrove forest was not significantly different from that of intact mangrove forest.
\end{abstract}

Keywords: intact mangroves; restored mangroves; mono-specific plantation; multi species; soil carbon stock; northern Vietnam; climate change 


\section{Introduction}

Mangrove forests are well known for their ability to fix and store large amounts of atmospheric $\mathrm{CO}_{2}$ [1-4], one of the main greenhouse gases that contributes to global warming [5]. This carbon (C) is assimilated and stored in aboveground tree biomass (i.e., stems, branches, leaves and roots) and in soils as both belowground roots and trapped sediments [6]. Up to $90 \%$ of mangrove C stocks are stored in anaerobic and waterlogged soil conditions that inhibit microbial breakdown of $C$ and can result in long-term storage if left undisturbed [7-10]. This also results in mangroves storing 10-15\% of coastal sediment $\mathrm{C}$ stocks despite only representing $0.5 \%$ of the world's coastlines $[11,12]$. The ability to remove and store large amounts of $C$ has significantly increased the role mangroves play in the reduction of greenhouse gas emissions and thus climate change mitigation and adaptation [13].

Mangroves in Vietnam are mainly distributed in the estuarine areas of 29 coastal provinces. Total mangrove forest area of Vietnam was estimated at 408,500 ha in 1943 [14]. However, the area of mangroves dropped sharply over the past 70 years to 131,520 ha in 2016 [15] due to the aftermath of a destructive war and excessive exploitation of forests. In northern Vietnam, about 37,100 ha of mangroves were lost from 1964-1997 to deforestation for the creation of shrimp aquaculture ponds. Since 1994, thousands of ha of mangroves, mainly Kandelia obovata Sheue, Liu \& Yong and Sonneratia caseolaris (L.) Engl., have been replanted by the Vietnam Red Cross with support of the Danish and the Japanese Red Cross through the International Federation of Red Cross and Red Crescent Societies [16]. These mangroves protect coastal infrastructure (e.g., dikes, seawalls, villages) from storm damage, increase available aquatic resources for fishing, and remove and store $\mathrm{CO}_{2}$ from the atmosphere [17].

Above and belowground $C$ stocks have been studied to some extent in both southern and northern Vietnam. However, most studies have focused on intact and restored monotypic stands of Rhizophora apiculata Blume and K. obovata mangroves. In southern Vietnam, Fujimoto et al. [18] reported that soil $\mathrm{C}$ at $0-100 \mathrm{~cm}$ depth in mangroves of Ca Mau ranged from $258.51-479.29 \mathrm{Mg} / \mathrm{ha}$ and in mangroves of Can Gio ranged from 245.20-309.90 Mg/ha. More recently, Tue et al. [19] reported that total C stocks of the mangrove ecosystem (above and below ground) in Mui Ca Mau National Park ranged from 719.2 to $802.1 \mathrm{Mg} / \mathrm{ha}$. The total C stocks of mangroves in Can Gio and Ben Tre were 910.7 and $844.0 \mathrm{Mg} / \mathrm{ha}$, respectively [20,21]. In northern Vietnam, Ha et al. [22] reported that the total C stored in the soil and biomass of a 3-9-year-old K. obovata plantation in Xuan Thuy National Park ranged from 100.7-199.3 Mg/ha. Similarly, soil C stocks at 0-100 cm depth in a 1-9-year-old K. obovata plantation of Xuan Thuy National Park ranged from 68.37-92.18 Mg C/ha [23]. Cuc et al. [24] also reported that soil C stocks at 0-100 cm depth in a 3-10-year-old K. obovata plantation of Thai Binh province ranged from 52.84-85.16 Mg/ha. Few studies have compared $\mathrm{C}$ stocks among different monotypic plantations (i.e., S. caseolaris, A. corniculatum, K. obovata), mixed-species plantations, and intact mangroves in either region. The objectives of the present study were, thus, to assess soil $C$ stocks to understand soil $C$ sequestration in relation to mangrove types (restored vs. intact mangroves), mangrove species (mixed species vs. monospecies of $S$. caseolaris, A. corniculatum and K. obovata) and geographical locations across four coastal provinces in northern Vietnam. We focused on soil $\mathrm{C}$ for this study as it is the major store of $\mathrm{C}$ in mangrove forests.

\section{Materials and Methods}

The northern coast of Vietnam is located within a distinct monsoon climate zone with a rainy season from May to October and a dry season from November to April. The temperature and rainfall vary annually from 11.5 to $30.8^{\circ} \mathrm{C}$ and from 1500 to $2500 \mathrm{~mm}$, respectively. Tides are diurnal, with a mesotidal regime and a large tidal amplitude (3-4 m). The region has complex geomorphological and hydrological conditions, some of which are suitable for the development of mangroves. In Quang Ninh, well-developed coastal mudflats from riverine input are protected by nearshore islands and are little affected by storms, strong winds and waves, making them ideal locations for mangroves to colonize. Water salinity is fairly uniform throughout the year and ranges from $26 \%-28 \%$. In the remaining provinces (Thai Binh, Nam Dinh, Thanh Hoa), well-developed coastal areas have resulted 
from sediment inputs from the Thai Binh, Hong and Ma rivers. These accreted mudflats in Thai Binh, Nam Dinh and Thanh Hoa are larger than in Quang Ninh, but are subjected to strong winds and waves. The watersheds in Thai Binh, Nam Dinh and Thanh Hoa are larger than Quang Ninh and, as a result, these systems tend to have lower salinities that range from $0.5 \%$ o $25 \%$ o $[25,26]$.

The total area of mangroves in northern Vietnam decreased from 47,000 ha in the 1980s to 11,000 ha in the 1990s. This was mainly due to deforestation for the creation of shrimp aquaculture ponds. Today, the area of mangroves in northern Vietnam has increased to more than 31,200 ha. The recent increase in mangrove area is largely due to restoration efforts and protection policies; nearly $75 \%$ of the mangrove area has been intentionally restored [27,28]. Mangrove forests are dominated by trees of $S$. caseolaris, Bruguiera gymnorrhiza (L.) Lam., K. obovata, Aegiceras corniculatum (L.) Blanco, R. stylosa and Avicennia marina (Forssk.) Vierh. The restored mangroves were established mainly in Thai Binh, Nam Dinh, and Thanh Hoa provinces during 1993-1998, through planting of K. obovata, S. caseolaris, or both of these species (mixed).

A total of 96 soil cores were collected using a 6.4-cm open-face auger every $25 \mathrm{~m}(25,50,75,100,125$, and $150 \mathrm{~m}$ ) along 16 linear transects, that were $150 \mathrm{~m}$ long and perpendicular to the mangrove upland interface (6 cores along each transect) at Quang Ninh (4 transects), Thai Binh (5), Nam Dinh (4) and Thanh Hoa (3) in May and June of 2018. The sampling sites and transects are described in Figure 1 and Table 1. Five-cm-long soil samples were then collected at the 0-15-cm, 15-30-cm, 30-50-cm, 50-100-cm, and $>100-\mathrm{cm}$ intervals [29]. All wet soil samples were dried to a constant mass at $60{ }^{\circ} \mathrm{C}$ to determine the bulk density (BD) for each interval. The dried samples were ground by hand using a mortar and pestle, then sieved through a 2-mm mesh to remove any large roots or rocks before being analyzed for $\mathrm{C}$ content $(\% \mathrm{C})$. Bulk density was obtained by the ratio of dry mass per volume of wet sample. Due to limited resources, $C$ content in all soil samples was determined using the Walkley-Black method [30]. Carbon content of 50 randomly selected soil samples was also analyzed using the combustion method on a Thermo Scientific ${ }^{\mathrm{TM}}$ FlashSmart ${ }^{\mathrm{TM}}$ Elemental Analyzer (EA) to calculate correction coefficients for $C$ contents from the Walkley-Black method (WB). The regression relationship of WB with EA is $\mathrm{y}=0.667 \mathrm{x}+0.361\left(R^{2}=0.841, p<0.001\right)$.

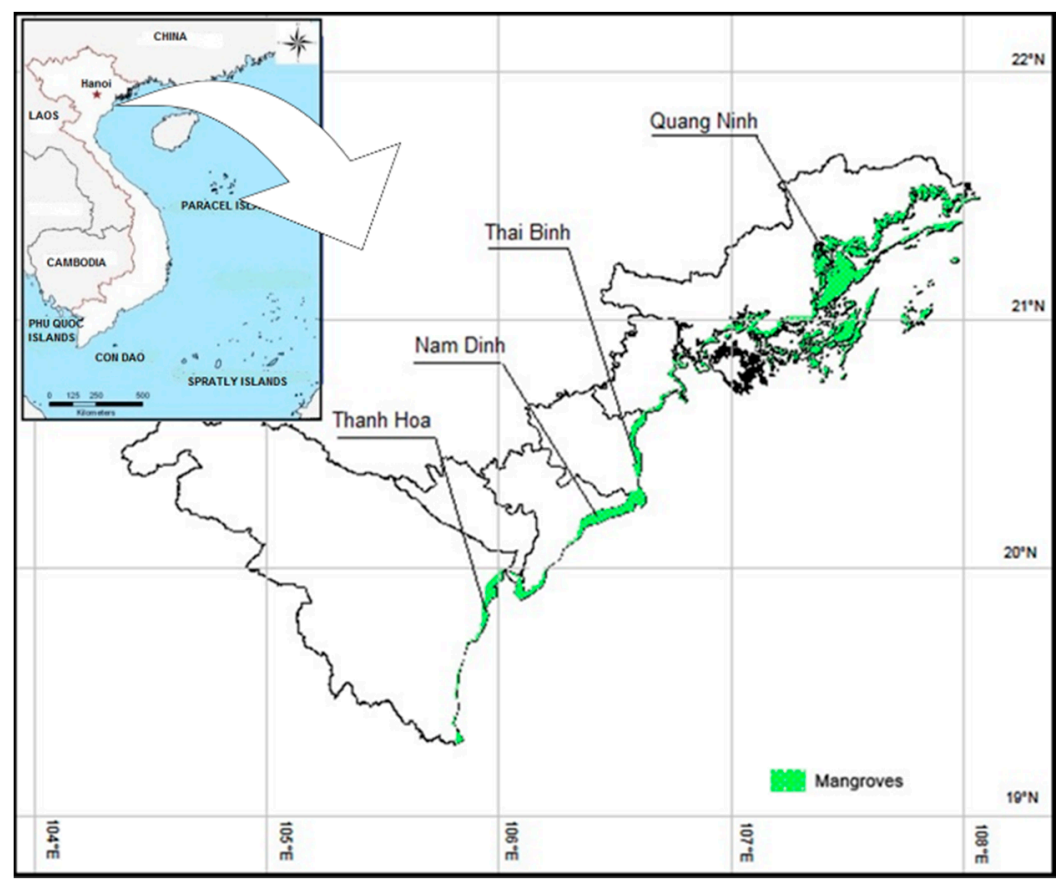

Figure 1. Location of study sites in northern Vietnam. 
Table 1. Mangrove descriptions of study sites and transects.

\begin{tabular}{cccccccc}
\hline No & Provinces & Transects & $\begin{array}{c}\text { Latitude } \\
(\mathbf{N})\end{array}$ & $\begin{array}{c}\text { Longitude } \\
\mathbf{( E )}\end{array}$ & Species & $\begin{array}{c}\text { Forest } \\
\text { Types }\end{array}$ & $\begin{array}{c}\text { Stand Age } \\
\text { (Years) }\end{array}$ \\
\hline 1 & Quang Ninh & TT & $21^{\circ} 11^{\prime} 29.21^{\prime \prime}$ & $107^{\circ} 23^{\prime} 5.9^{\prime \prime}$ & Mixed & Intact & - \\
2 & Quang Ninh & TH & $21^{\circ} 14^{\prime} 40.6^{\prime \prime}$ & $107^{\circ} 23^{\prime} 19.3^{\prime \prime}$ & Ac & Intact & - \\
3 & Quang Ninh & TB1 & $21^{\circ} 14^{\prime} 49.7^{\prime \prime}$ & $107^{\circ} 24^{\prime} 34.2^{\prime \prime}$ & Bg & Intact & - \\
4 & Quang Ninh & TB2 & $21^{\circ} 14^{\prime} 44.1^{\prime \prime}$ & $107^{\circ} 24^{\prime} 39.2^{\prime \prime}$ & Ko & Restored & 22 \\
5 & Thai Binh & DL1 & $20^{\circ} 26^{\prime} 40.7^{\prime \prime}$ & $106^{\circ} 36^{\prime} 13.8^{\prime \prime}$ & Sc & Restored & 23 \\
6 & Thai Binh & DL2 & $20^{\circ} 26^{\prime} 32.7^{\prime \prime}$ & $106^{\circ} 36^{\prime} 32.0^{\prime \prime}$ & Sc & Restored & 23 \\
7 & Thai Binh & DL3 & $20^{\circ} 25^{\prime} 20.9^{\prime \prime}$ & $106^{\circ} 36^{\prime} 14.7^{\prime \prime}$ & Ko & Restored & 25 \\
8 & Thai Binh & NP1 & $20^{\circ} 18^{\prime} 14.5^{\prime \prime}$ & $106^{\circ} 35^{\prime} 54.6^{\prime \prime}$ & Ko & Restored & 24 \\
9 & Thai Binh & NP2 & $20^{\circ} 18^{\prime} 19.0^{\prime \prime}$ & $106^{\circ} 35^{\prime} 54.8^{\prime \prime}$ & Ko & Restored & 24 \\
10 & Nam Dinh & XT1 & $20^{\circ} 15^{\prime} 02.6^{\prime \prime}$ & $106^{\circ} 34^{\prime} 19.5^{\prime \prime}$ & Ac & Intact & - \\
11 & Nam Dinh & XT2 & $20^{\circ} 13^{\prime} 58.8^{\prime \prime}$ & $106^{\circ} 33^{\prime} 56.5^{\prime \prime}$ & Ac & Intact & - \\
12 & Nam Dinh & XT3 & $20^{\circ} 14^{\prime} 05.7^{\prime \prime}$ & $106^{\circ} 34^{\prime} 48.7^{\prime \prime}$ & Mixed & Restored & 21 \\
13 & Nam Dinh & XT4 & $20^{\circ} 13^{\prime} 36.3^{\prime \prime}$ & $106^{\circ} 34^{\prime} 36.4^{\prime \prime}$ & Mixed & Restored & 20 \\
14 & Thanh Hoa & DT & $19^{\circ} 56^{\prime} 52.7^{\prime \prime}$ & $105^{\circ} 59^{\prime} 31.5^{\prime \prime}$ & Sc & Restored & 23 \\
15 & Thanh Hoa & DH & $19^{\circ} 56^{\prime} 34.6^{\prime \prime}$ & $105^{\circ} 58^{\prime} 59.8^{\prime \prime}$ & Ko & Restored & 21 \\
16 & Thanh Hoa & NP & $19^{\circ} 56^{\prime} 20.8^{\prime \prime}$ & $105^{\circ} 58^{\prime} 35.8^{\prime \prime}$ & Sc & Restored & 20 \\
\hline
\end{tabular}

Notes: $\mathrm{Ac}=A$. corniculatum $(\mathrm{L}$.$) Blanco; \mathrm{Bg}=$ B. gymnorrhiza $(\mathrm{L}$.$) Lam.; Ko =$ K. obovate Sheue, Liu \& Yong; $\mathrm{Sc}=$ S. Caseolaris (L.) Engl.

Soil C stocks were then determined for each soil core interval by multiplying the interval length by the $\mathrm{BD}$ of the subsample and the whole $\% \mathrm{C}$ value of the subsample. Intervals were then summed up for the entire 2-m-long core from each plot and then averaged across mangrove type, mangrove species, and province. One-way analysis of variance (ANOVA) was used to compare $C$ stocks between mangrove type (intact and restored mangroves) as well as across mangrove species (mixed species, S. caseolaris, A. corniculatum and K. obovata) and the different provinces (Quang Ninh, Thai Binh, Nam Dinh and Thanh Hoa). Fisher's least significant difference (LSD) test was used to perform all pairwise comparisons among group means. All values reported are mean values \pm standard error (SE).

\section{Results and Discussion}

\subsection{Soil Carbon in Intact vs. Restored Mangroves}

The average soil BD of intact mangrove forests in northern Vietnam $\left(0.91 \pm 0.04 \mathrm{~g} / \mathrm{cm}^{3}\right)$ was significantly smaller $(p<0.05)$ than that of restored mangrove forests $\left(1.03 \pm 0.03 \mathrm{~g} / \mathrm{cm}^{3}\right)$. In contrast, the average $\% \mathrm{C}$ and soil carbon density of intact mangrove forests $\left(2.43 \pm 0.47 \%\right.$ and $19.89 \pm 2.92 \mathrm{mg} / \mathrm{cm}^{3}$, respectively) were significantly greater $(p<0.05)$ than that of restored mangrove forests $(1.46 \pm 0.13 \%$ and $13.34 \pm 1.31 \mathrm{mg} / \mathrm{cm}^{3}$, respectively). However, in the upper $100 \mathrm{~cm}$, the $\mathrm{BD}$ and $\% \mathrm{C}$ of the intact mangrove forests were significantly different from the restored mangrove forest $(p<0.05)$. Below this depth $(>100 \mathrm{~cm})$, the difference was not significant $(p>0.05)$ (Figure 2$)$. The results suggest that both intact mangroves and restored mangroves originally had equivalent sedimentary substrate. This is also revealed by our field observation that the bottom layers of both mangrove types were mostly composed of sand. Similar to \%C, soil carbon density in the upper $100 \mathrm{~cm}$ depth in the intact mangrove forests was significantly greater than in restored mangrove forests $(p<0.05)$. Below this depth $(>100 \mathrm{~cm})$, the difference was not significant $(p>0.05)$. Soil carbon density in both mangrove types increased from 15.42 to $27.20 \mathrm{mg} / \mathrm{cm}^{3}$ between 0 and $15 \mathrm{~cm}$ depth, then declined rapidly $\left(27.20-10.69 \mathrm{mg} / \mathrm{cm}^{3}\right)$ in the middle layers $(15-100 \mathrm{~cm})$ and slowly at the bottom of the core $\left(10.69-8.63 \mathrm{mg} / \mathrm{cm}^{3}\right)$. The differences in $\mathrm{BD}, \% \mathrm{C}$ and soil carbon density in the upper layers may result from the different stand ages and development of mangrove roots in the upper $50 \mathrm{~cm}$. Ha et al. [22] reported a linear relationship between carbon stocks in the soil and in the roots and suggested that the roots are an important source of organic carbon accumulation in mangrove soils. Moreover, Komiyama et al. [31], Tamooh et al. [32] 
and Castañeda-Moya et al. [33] demonstrated that mangrove root densities as well as their carbon content not only varied with depth but also with mangrove stand age.
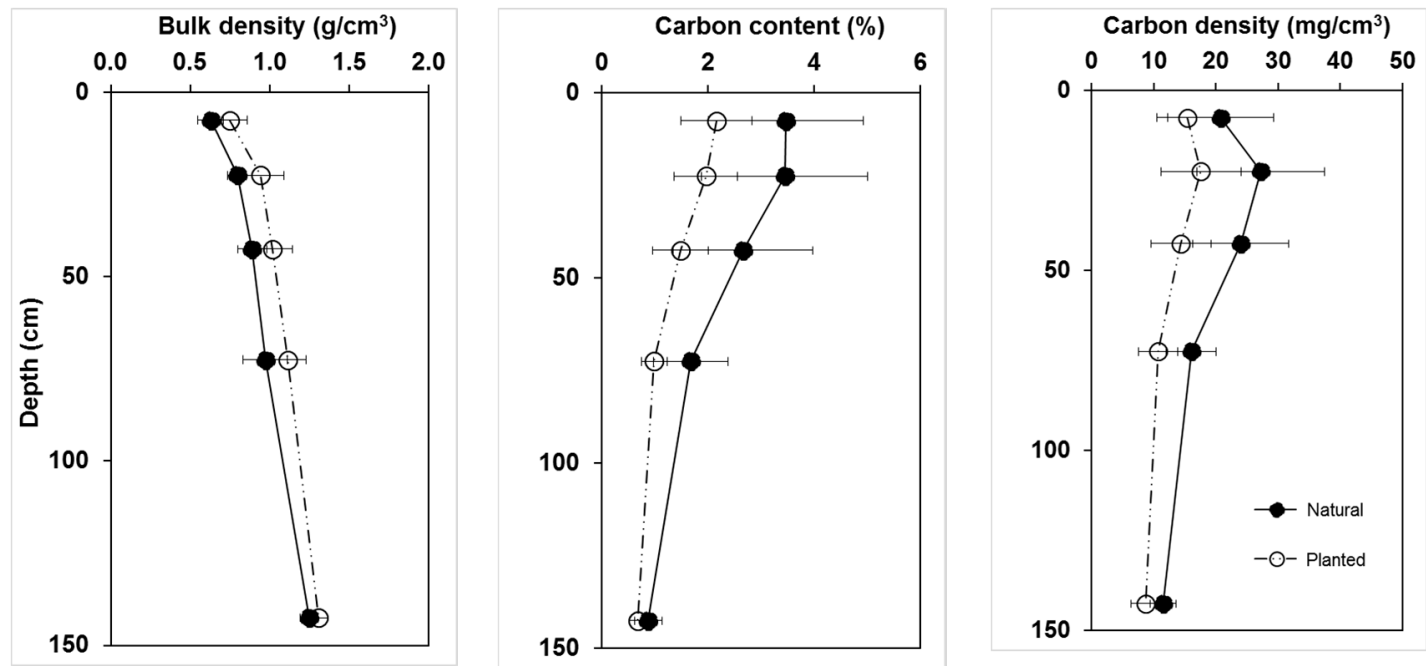

Figure 2. Soil properties according to forest type in northern Vietnam.

Table 2 shows that the average soil $\mathrm{C}$ stocks between mangrove types at the depth intervals of $0-15 \mathrm{~cm}, 15-30 \mathrm{~cm}$, and $>100 \mathrm{~cm}$ were similar $(p>0.05)$, but significantly different at the depth intervals of $30-50 \mathrm{~cm}$ and $50-100 \mathrm{~cm}(p<0.05)$. The total soil C stock of intact mangrove forest $(300.68 \pm 51.61 \mathrm{Mg} / \mathrm{ha})$ was not significantly different from that of restored mangroves $(217.74 \pm 16.82 \mathrm{Mg} / \mathrm{ha})(p>0.05)$. Gao et al. [34] reported that forest age could be one of the key factors affecting soil C stock. Donato et al. [1] and Lovelock et al. [35] also reported that mature mangrove plants could contribute much more soil $\mathrm{C}$ stock and biomass than younger plants. However, Lunstrum and Chen [36] found no significant variation in soil $C$ stock between $S$. apetala and K. obovata after six years of planting. Our study indicated that 20-25-year-old restored mangrove forest could have similar levels of soil C stock as intact mangrove forest.

Table 2. Soil carbon pools (mean $\pm \mathrm{SE})(\mathrm{Mg} / \mathrm{ha})$ according to forest types in the study area. The letters in each row denote the differences between mangrove types.

\begin{tabular}{cccc}
\hline Depth $(\mathbf{c m})$ & Restored Mangroves & Intact Mangroves & $p$-Value \\
\hline $0-15$ & $22.71 \pm 2.15 \mathrm{a}$ & $28.75 \pm 7.64 \mathrm{a}$ & 0.296 \\
$15-30$ & $25.82 \pm 2.82 \mathrm{a}$ & $38.03 \pm 8.78 \mathrm{a}$ & 0.103 \\
$30-50$ & $27.85 \pm 2.51 \mathrm{a}$ & $46.24 \pm 9.07 \mathrm{~b}$ & 0.014 \\
$50-100$ & $53.38 \pm 4.70 \mathrm{a}$ & $80.05 \pm 13.92 \mathrm{~b}$ & 0.036 \\
$>100$ & $87.98 \pm 7.41 \mathrm{a}$ & $107.60 \pm 14.02 \mathrm{a}$ & 0.254 \\
Total & $217.74 \pm 16.82 \mathrm{a}$ & $300.68 \pm 51.61 \mathrm{a}$ & 0.066 \\
\hline
\end{tabular}

\subsection{Soil Carbon among Different Species}

In northern Vietnam, average soil BD was the highest in $S$. caseolaris $\left(1.07 \pm 0.07 \mathrm{~g} / \mathrm{cm}^{3}\right)$, followed by $K$. obovata $\left(1.03 \pm 0.04 \mathrm{~g} / \mathrm{cm}^{3}\right)$, A. corniculatum $\left(0.95 \pm 0.04 \mathrm{~g} / \mathrm{cm}^{3}\right)$ and mixed-species mangrove forest $\left(0.90 \pm 0.05 \mathrm{~g} / \mathrm{cm}^{3}\right)$. In contrast, average $\% \mathrm{C}$ and soil carbon density were the highest in mixed-species mangrove forest $\left(2.33 \pm 0.39 \mathrm{~g} / \mathrm{cm}^{3}\right.$ and $18.76 \pm 3.26 \mathrm{mg} / \mathrm{cm}^{3}$, respectively), followed by A. corniculatum $\left(1.84 \pm 0.53 \mathrm{~g} / \mathrm{cm}^{3}\right.$ and $16.65 \pm 3.34 \mathrm{mg} / \mathrm{cm}^{3}$, respectively), S. caseolaris $\left(1.51 \pm 0.15 \mathrm{~g} / \mathrm{cm}^{3}\right.$ and $14.85 \pm 1.88 \mathrm{mg} / \mathrm{cm}^{3}$, respectively) and $K$. obovata $\left(1.28 \pm 0.18 \mathrm{~g} / \mathrm{cm}^{3}\right.$ and $11.42 \pm 1.81 \mathrm{mg} / \mathrm{cm}^{3}$, respectively). The soil $\mathrm{BD}$ of all species increased with depth, while $\% \mathrm{C}$ and carbon density decreased with depth (Figure 3). Among different species, there was no significant difference of soil BD, \%C and carbon density in the upper $100 \mathrm{~cm}(p>0.05)$. However, below this depth, the differences were 
statistically significant $(p<0.05)$, in which soil BD, \%C and carbon density of $K$. obovata mangroves were significantly lower than for other species or mixed mangroves $(p<0.05)$.
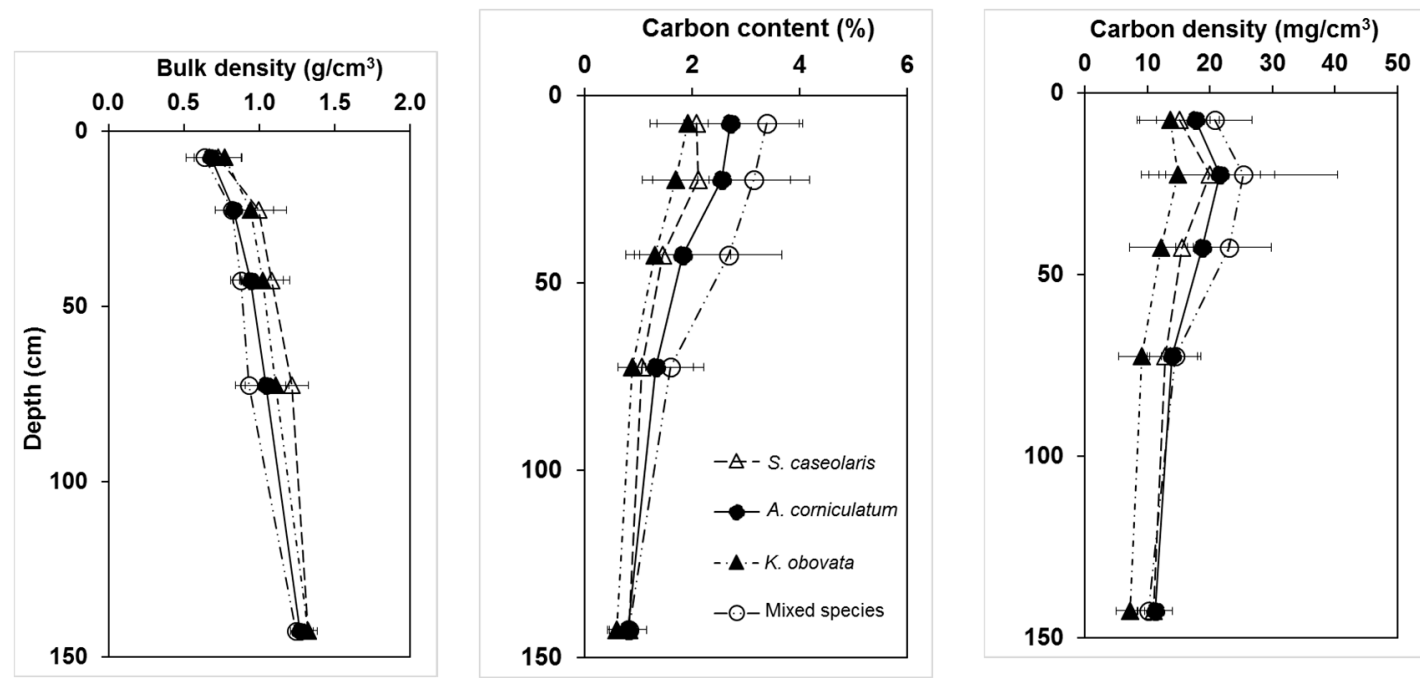

Figure 3. Soil properties according to mangrove species in northern Vietnam.

Hien et al. [17] suggested that, in K. obovata mangroves, root biomass may be an important source of soil organic carbon enrichment, but the contribution of mangrove products in deeper layers than $100 \mathrm{~cm}$ was negligible; meanwhile, Marchand et al. [37,38] also reported that, in some mangroves, the root system was considered to be the main contributor of the accumulation of organic matters in mangrove soils. However, Alongi [12], Bouillon et al. [39], Barr et al. [40] and Li et al. [41] suggested that soil organic carbon in mangrove forests mainly originates from the decomposition of mangrove litter or from adjacent coastal waves, tides and rivers. The species with different root system would also impact soil organic carbon.

Table 3 shows that average soil $C$ stocks among species at depth intervals of $0-15 \mathrm{~cm}, 15-30 \mathrm{~cm}$, and 50-100 cm were similar $(p>0.05)$, but significantly differed at deeper soil depth intervals of $30-50 \mathrm{~cm}$ and $>100 \mathrm{~cm}(p<0.05)$. In northern Vietnam, mixed and A. corniculatum mangrove stands have a longer history of establishment compared to other species and also have pneumatophores (i.e., vertical roots arising from shallow, horizontal roots) and thus a more complicated tertiary structure. This could explain the higher $C$ stocks in the upper intervals, which would be influenced by the higher trapping efficiencies of these root systems and thus greater deposition and sedimentation rate but lower erosion rate compared to the younger S. caseolaris and K. obovata mangroves [25]. Table 3 also shows a significant difference in total soil $C$ stocks among species $(p<0.05)$. Fisher's LSD analysis indicated that the differences in total soil $C$ stock among mixed, $S$. caseolaris and A. corniculatum mangroves $(289.75 \pm 33.28 \mathrm{Mg} / \mathrm{ha}, 255.67 \pm 13.11 \mathrm{Mg} / \mathrm{ha}$ and $278.15 \pm 43.86 \mathrm{Mg} / \mathrm{ha}$, respectively) were not significant $(p>0.05)$. However, the total soil C stock of $K$. obovata $(174.04 \pm 20.38 \mathrm{Mg} / \mathrm{ha})$ was significantly lower than that of other species $(p<0.05)$. Gao et al. [34] commented that mangrove forests with different species would have different capabilities of soil carbon sequestration and different contributions to carbon stock. Ha et al. [22], Komiyama et al. [31], Tamooh et al. [32] and Castañeda-Moya et al. [33] also demonstrated that mangrove root density as well as soil C stock not only varied with depth and stand ages but also with mangrove species. 
Table 3. Soil carbon pools (mean $\pm \mathrm{SE})(\mathrm{Mg} / \mathrm{ha})$ according to mangrove species in the study area. The letters in each row denote the differences among species.

\begin{tabular}{cccccc}
\hline Depth $(\mathbf{c m})$ & Mixed Species & S. Caseolaris & A. Corniculatum & K. Obovata & $p$-Value \\
\hline $0-15$ & $31.10 \pm 1.07 \mathrm{a}$ & $22.63 \pm 5.37 \mathrm{a}$ & $26.57 \pm 7.79 \mathrm{a}$ & $19.64 \pm 3.32 \mathrm{a}$ & 0.292 \\
$15-30$ & $37.92 \pm 4.83 \mathrm{a}$ & $28.60 \pm 8.04 \mathrm{ac}$ & $32.41 \pm 7.56 \mathrm{ab}$ & $21.19 \pm 3.50 \mathrm{bc}$ & 0.193 \\
$30-50$ & $46.23 \pm 7.72 \mathrm{a}$ & $30.95 \pm 6.55 \mathrm{~b}$ & $37.52 \pm 4.92 \mathrm{ab}$ & $21.47 \pm 2.47 \mathrm{~b}$ & 0.009 \\
$50-100$ & $72.36 \pm 11.75 \mathrm{a}$ & $64.15 \pm 3.23 \mathrm{ab}$ & $69.85 \pm 11.69 \mathrm{ac}$ & $43.62 \pm 7.60 \mathrm{bc}$ & 0.107 \\
$>100$ & $102.14 \pm 9.71 \mathrm{a}$ & $109.35 \pm 6.92 \mathrm{a}$ & $111.81 \pm 16.52 \mathrm{a}$ & $68.12 \pm 6.44 \mathrm{~b}$ & 0.011 \\
Total & $289.75 \pm 33.28 \mathrm{a}$ & $255.67 \pm 13.11 \mathrm{a}$ & $278.15 \pm 43.86 \mathrm{a}$ & $174.04 \pm 20.38 \mathrm{~b}$ & 0.029 \\
\hline
\end{tabular}

\subsection{Soil Carbon among Provinces}

The BD in mangrove soil was the highest in Thanh Hoa, followed by Thai Binh, Nam Dinh, and then Quang Ninh, with mean values of $1.12 \pm 0.05,1.01 \pm 0.05,0.97 \pm 0.02$, and $0.89 \pm 0.04 \mathrm{~g} / \mathrm{cm}^{3}$, respectively. In all provinces, $\mathrm{BD}$ increased with depth. However, among the provinces, there was a significant difference in $\mathrm{BD}$ in the upper $50 \mathrm{~cm}(p<0.05)$; below this depth, there was no significant difference $(p>0.05)$. Fisher's LSD analysis indicated that the differences in BD in the upper $50 \mathrm{~cm}$ across sites were driven by differences between Thanh Hoa and Quang Ninh (Figure 4).
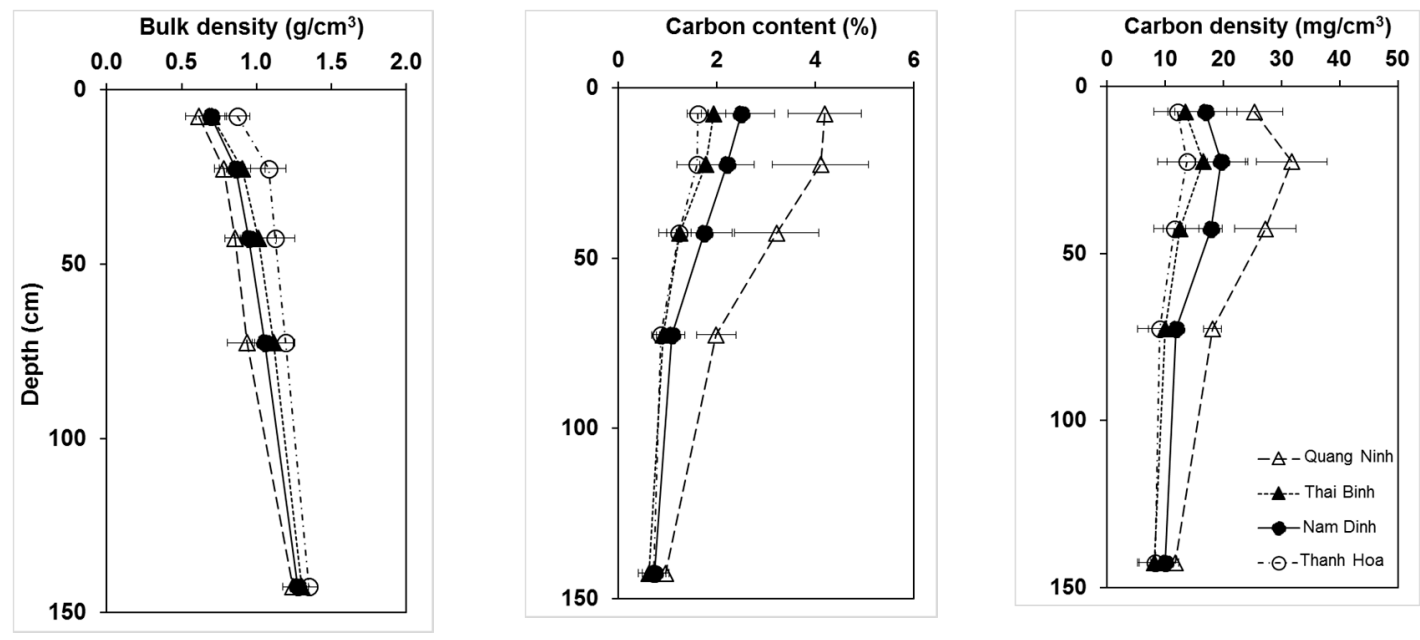

Figure 4. Soil properties according to provinces in northern Vietnam.

In contrast to the $\mathrm{BD}$, soil $\% \mathrm{C}$ in all sites decreased with depth (Figure 4). The mean value of $\% \mathrm{C}$ in Quang Ninh $(2.89 \pm 0.30 \%)$ was almost twice the \%C values in remaining provinces: Thanh Hoa $(1.20 \pm 0.09 \%)$, Thai Binh (1.29 $\pm 0.15 \%)$ and Nam Dinh $(1.65 \pm 0.23 \%)$. Mangrove soil carbon density in the four provinces increased from $12.17 \pm 2.38$ to $31.78 \pm 3.04 \mathrm{mg} / \mathrm{cm}^{3}$ between 0 and $30 \mathrm{~cm}$ depth, then declined rapidly to $9.03 \pm 2.13 \mathrm{mg} / \mathrm{cm}^{3}$ in the middle layers $(30-100 \mathrm{~cm})$, and declined slowly to $8.33 \pm 1.59 \mathrm{mg} / \mathrm{cm}^{3}$ at the bottom of the core. In the upper $50 \mathrm{~cm}$, significant differences in carbon density among the different provinces were also observed $(p<0.05)$. Below this depth, the differences were not significant (Figure 4). The differences in BD, \%C and soil carbon density were likely due to the different environmental conditions of the sites previously described. Quang Ninh mangroves are protected by nearshore islands and thus not affected by strong waves. As a result, less organic matter washes away. The $\mathrm{BD}, \% \mathrm{C}$ and soil carbon density from this study were close to those measured in Xuan Thuy National Park of Vietnam [17] and in other Asian mangroves, such as in China [36,42] and Thailand [43], but lower than those measured in the Indo-Pacific [1].

There was a significant difference in the total soil $C$ stocks among provinces $(p<0.05)$. However, Fisher's LSD analysis indicated that the total soil C stocks of Quang Ninh $(323.89 \pm 28.43 \mathrm{Mg} / \mathrm{ha})$ were not significantly different from Nam Dinh $(249.81 \pm 19.09 \mathrm{Mg} / \mathrm{ha})$, but were significantly greater 
than Thai Binh (201.42 $\pm 27.65 \mathrm{Mg} / \mathrm{ha})$ and Thanh Hoa (178.98 $\pm 30.82 \mathrm{Mg} / \mathrm{ha})$. Quang Ninh also had significantly greater soil $\mathrm{C}$ stocks than the other three provinces in almost soil layers, while soil C stocks did not differ among the remaining three provinces at each depth interval (Table 4). This is probably because of their different geomorphological characteristics, as described in the previous section. Quang Ninh and Nam Dinh mangroves have also developed over a longer period of time compared to the other two provinces [25]. Moreover, the differences in the bioturbation, climatic and physicochemical factors among provinces could also influence the soil carbon C stock $[2,34,44,45]$.

Table 4. Soil carbon pools (mean $\pm \mathrm{SE})(\mathrm{Mg} / \mathrm{ha})$ according to provinces in the study area. The letters in each row denote the differences among provinces.

\begin{tabular}{cccccc}
\hline Depth (cm) & Quang Ninh & Thai Binh & Nam Dinh & Thanh Hoa & $p$-Value \\
\hline $0-15$ & $35.42 \pm 5.78 \mathrm{a}$ & $20.23 \pm 4.47 \mathrm{~b}$ & $25.44 \pm 4.01 \mathrm{a}$ & $16.53 \pm 5.89 \mathrm{~b}$ & 0.013 \\
$15-30$ & $43.69 \pm 5.42 \mathrm{a}$ & $24.77 \pm 5.17 \mathrm{~b}$ & $29.35 \pm 6.36 \mathrm{~b}$ & $17.21 \pm 2.17 \mathrm{~b}$ & 0.013 \\
$30-50$ & $47.16 \pm 8.27 \mathrm{a}$ & $25.17 \pm 3.97 \mathrm{~b}$ & $35.69 \pm 4.03 \mathrm{a}$ & $20.94 \pm 3.32 \mathrm{~b}$ & 0.010 \\
$50-100$ & $89.08 \pm 4.97 \mathrm{a}$ & $50.38 \pm 6.45 \mathrm{~b}$ & $59.69 \pm 5.40 \mathrm{~b}$ & $40.95 \pm 10.47 \mathrm{~b}$ & 0.003 \\
$>100$ & $108.54 \pm 13.09 \mathrm{a}$ & $80.87 \pm 12.67 \mathrm{~b}$ & $99.65 \pm 11.90 \mathrm{~b}$ & $83.35 \pm 15.92 \mathrm{~b}$ & 0.047 \\
Total & $323.89 \pm 28.43 \mathrm{a}$ & $201.42 \pm 27.65 \mathrm{~b}$ & $249.81 \pm 19.09 \mathrm{a}$ & $178.98 \pm 30.82 \mathrm{~b}$ & 0.022 \\
\hline
\end{tabular}

\section{Conclusions}

The results of the present study show that the soil $\mathrm{C}$ stock of mangrove forests in northern Vietnam varies depending on geographical location and mangrove species. The highest soil C stock was estimated for Quang Ninh, where intact mangroves have grown steadily for a long time, while the lowest value was at Thanh Hoa, where restored mangroves have been developed since 1995-1998. Soil C stocks of $S$. caseolaris, A. corniculatum and mixed species were significantly larger than that of K. obovata. The study also confirmed that soil C stock of 20-25-year-old restored mangrove forest was not significantly different from that of intact mangrove forest. This demonstrated that mangrove restoration can help to sequester blue carbon, which is a crucial aspect to mitigating climate change in northern Vietnam.

Author Contributions: Conceptualization, P.H.T., S.S., and R.A.M.; investigation, P.H.T., N.T.H.H., V.V.T., M.S.T., P.V.Q., S.S., and R.A.M.; methodology, P.H.T., N.T.H.H., M.S.T., P.V.Q., S.S., and R.A.M.; writing-original draft, P.H.T.; writing — review and editing, S.S. and R.A.M. All authors have read and agreed to the published version of the manuscript.

Funding: This research was funded by United States for Forestry Service International Programs (USFS/IP).

Acknowledgments: We acknowledge the local governments of Quang Ninh, Thai Binh, Nam Dinh and Thanh Hoa provinces for facilitating entry to the research sites, and the researchers of Mangrove Ecosystem Research Center for their contribution in soil sample collection.

Conflicts of Interest: The authors declare no conflict of interest.

\section{References}

1. Donato, D.C.; Kauffman, J.B.; Murdiyarso, D.; Kurnianto, S.; Stidham, M.; Kanninen, M. Mangroves among the most carbon-rich forests in the tropics. Nat. Geosci. 2011, 4, 293-297. [CrossRef]

2. Murdiyarso, D.; Purbopuspito, J.; Kauffman, J.B.; Warren, M.W.; Sasmito, S.D.; Donato, D.C.; Manuri, S.; Krisnawati, H.; Taberima, S.; Kurnianto, S. The potential of Indonesian mangrove forests for global climate change mitigation. Nat. Clim. Chang. 2015, 5, 1089-1092. [CrossRef]

3. Soper, F.M.; MacKenzie, R.A.; Sharma, S.; Cole, T.G.; Litton, C.M.; Sparks, J.P. Non-native mangroves support carbon storage, sediment carbon burial, and accretion of coastal ecosystems. Glob. Chang. Biol. 2019, 25, 4315-4326. [CrossRef] [PubMed]

4. Sharma, S.; MacKenzie, R.A.; Tieng, T.; Soben, K.; Tulyasuwan, N.; Resanond, A.; Blate, G.; Litton, C.M. The impacts of degradation, deforestation and restoration on mangrove ecosystem carbon stocks across Cambodia. Sci. Total Environ. 2020, 706, 135416. [CrossRef] [PubMed] 
5. IPCC. Climate Change 2007: Impacts, Adaptation and Vulnerability. In Contribution of Working Group II to the Fourth Assessment Report of the Intergovernmental Panel on Climate Change; Parry, M.L., Canziani, O.F., Palutikof, J.P., van der Linden, P.J., Hanson, C.E., Eds.; Cambridge University Press: Cambridge, UK, 2007.

6. Alongi, D.M. Carbon sequestration in mangrove forests. Carbon Manag. 2012, 3, 313-322. [CrossRef]

7. Atwood, T.B.; Connolly, R.M.; Almahasheer, H.; Carnell, P.E.; Duarte, C.M.; Lewis, C.J.E.; Irigoien, X.; Kelleway, J.J.; Lavery, P.S.; Macreadie, P.I.; et al. Global patterns in mangrove soil carbon stocks andlosses. Nat. Clim. Chang. 2017, 7, 523-528. [CrossRef]

8. Kauffman, J.B.; Adame, M.F.; Arifanti, V.B.; Schile-Beers, L.M.; Bernardino, A.F.; Bhomia, R.K.; Donato, A.C.; Feller, I.C.; Ferreira, T.O.; Garcia, M.D.C.J.; et al. Total ecosystem carbon stocks of mangroves across broad global environmental and physical gradients. Ecol. Monogr. 2020, 90, e01405. [CrossRef]

9. Bukoski, J.J.; Elwin, A.; MacKenzie, R.A.; Sharma, S.; Purbopuspito, J.; Kopania, B.; Apwong, M.; Poolsiri, R.; Potts, M.D. The role of predictive model data in designing mangrove forest carbon programs. Environ. Res. Lett. 2020, in press. [CrossRef]

10. Friess, D.A.; Yando, E.S.; Abuchahla, G.M.; Adams, J.B.; Cannicci, S.; Canty, S.W.; Cavanaugh, K.C.; Connolly, R.M.; Cormier, N.; Dahdouh-Guebas, F.; et al. Mangroves give cause for conservation optimism, for now. Curr. Biol. 2020, 30, R153-R154. [CrossRef] [PubMed]

11. Giri, C.; Ochieng, E.; Tieszen, L.L.; Zhu, Z.; Singh, A.; Loveland, T.; Masek, J.; Duke, N. Status and distribution of mangrove forests of the world using earth observation satellite data. Glob. Ecol. Biogeogr. 2011, 20, 154-159. [CrossRef]

12. Alongi, D.M. Carbon cycling and storage in mangrove forests. Annu. Rev. Mar. Sci. 2014, 6, 195-219. [CrossRef] [PubMed]

13. Macreadie, P.I.; Anton, A.; Raven, J.A.; Beaumont, N.; Connolly, R.M.; Friess, D.A.; Kelleway, J.J.; Kennedy, H.; Kuwae, T.; Lavery, P.S. The future of Blue Carbon science. Nat. Commun. 2019, 10, 1-13. [CrossRef] [PubMed]

14. Maurand, P. L'Indochine forestiere; Inst. Rech. Agron. Indochine: Paris, France, 1943.

15. Vietnam Ministry of Agriculture and Rural Development. Decision No 3158/QD-BNNTCLN Dated July 27, 2016; Vietnam Ministry of Agriculture and Rural Development: Ha Noi, Vietnam, 2016. (In Vietnamese)

16. International Federation of Red Cross and Red Crescent Societies. Planting Protection: Evaluation of Community-Based Mangrove Reforestation and Disaster Preparedness Programme, 2006-2010; IFRC and Red Crescent Societies: Geneva, Switzerland, 2010.

17. Hien, H.T.; Marchand, C.; Aimé, J.; Nhon, D.H.; Hong, P.N.; Tung, N.X.; Cuc, N.T.K. Belowground carbon sequestration in a mature planted mangroves (Northern Viet Nam). For. Ecol. Manag. 2018, 407, 191-199.

18. Fujimoto, K.; Miyagi, T.; Hiroshi, A.; Tamon, M.; Masakazu, H.; Tuan, M.S.; Phuong, D.X.; Nam, V.N.; Hong, P.N. Belowground carbon sequenstration of mangrove forests in southern Vietnam. In Organic Material and Sea-Level Change in Mangrove Habitat; Miyagi, T., Ed.; Tohoku-gakuin University: Sendai, Japan, 2000; pp. 30-36.

19. Tue, N.T.; Dung, L.V.; Nhuan, M.T.; Omori, K. Carbon storage of a tropical mangrove forest in Mui Ca Mau National Park, Vietnam. Catena 2014, 121, 119-126. [CrossRef]

20. Dung, L.V.; Tue, N.T.; Nhuan, M.T.; Omori, K. Carbon storage in a restored mangrove forest in Can Gio Mangrove Forest Park, Mekong Delta, Vietnam. For. Ecol. Manag. 2016, 380, 31-40. [CrossRef]

21. Nam, V.N.; Sasmito, S.D.; Murdiyarso, D.; Purbopuspito, J.; MacKenzie, R.A. Carbon stocks in artificially and naturally regenerated mangrove ecosystems in the Mekong Delta. Wetl. Ecol. Manag. 2016, 24, 231-244. [CrossRef]

22. Ha, N.T.; Yoneda, R.; Ninomiya, I.; Harada, K.; Tan, V.D.; Tuan, M.S.; Hong, P.N. The effects of stand-age and inundation on carbon accumulation in mangrove plantation soil in Nam Dinh, Northern Vietnam. Tropics 2004, 14, 21-37.

23. Tuan, M.S.; Hanh, N.T.H. Carbon accumulation of Kandelia obovata (Sheue, Liu \& Yong) plantation in the coastal area of Giao Thuy district, Nam Dinh province. VAST J. Biol. 2009, 31, 57-65. (In Vietnamese)

24. Cuc, T.K.N.; Ninomiya, I.; Long, N.T.; Tri, N.H. Belowground carbon accumulation in young Kandelia candel (L.) Blanco plantations in Thai Binh river mouth. Int. J. Ecol. Dev. 2009, 12, 107-117.

25. Hong, P.N.; San, H.T. Mangroves of Vietnam; IUCN: Bangkok, Thailand, 1993.

26. Cu, V.N. Coastal and Estuarine Shoals in the North of Vietnam; Vietnam Academy of Science and Technology: Hanoi, Vietnam, 2006. (In Vietnamese) 
27. Que, N.D.; Dai, V.V. Establishment of Coastal Protection Mangrove Forests: Current Status and Solutions; National Agriculture Extension Center: Hanoi, Vietnam, 2015. (In Vietnamese)

28. Vietnam Administration of Forestry. Report on the Development of a Database for the Coastal Forest of Vietnam; Vietnam Administration of Forestry: Hanoi, Vietnam, 2019; Unpublished.

29. Kauffman, J.B.; Donato, D.C. Protocols for the Measurement, Monitoring and Reporting of Structure, Biomass and Carbon Stocks in Mangrove Forests; Working Paper 86; CIFOR: Bogor, Indonesia, 2012.

30. Schumacher, B.A. Methods for the Determination of Total Organic Carbon in Soils and Sediments; EPA/600/R-02/069 (NTIS PB2003-100822); U.S. Environmental Protection Agency: Washington, DC, USA, 2002.

31. Komiyama, A.; Havanond, S.; Srisawatt, W.; Mochida, Y.; Fujimoto, K.; Ohnishi, T.; Ishihara, S.; Miyagi, T. Top/root biomass ratio of a secondary mangrove (Ceriops tagal (Perr.) C.B. Rob.) forest. For. Ecol. Manag. 2000, 139, 127-134. [CrossRef]

32. Tamooh, F.; Huxham, M.; Karachi, M.; Mencuccini, M.; Kairo, J.G.; Kirui, B. Belowground root yield and distribution in natural and replanted mangrove forests at Gazi bay, Kenya. For. Ecol. Manag. 2008, 256, 1290-1297. [CrossRef]

33. Castañeda-Moya, E.; Twilley, R.R.; Rivera-Monroy, V.H.; Marx, B.D.; Coronado-Molina, C.; Ewe, S.M.L. Patterns of root dynamics in mangrove forests along environmental gradients in the Florida Coastal Everglades, USA. Ecosystems 2011, 14, 1178-1195. [CrossRef]

34. Gao, Y.; Zhou, J.; Wang, L.; Guo, J.; Feng, J.; Wu, H.; Lin, G. Distribution patterns and controlling factors for the soil organic carbon in four mangrove forests of China. Glob. Ecol. Conserv. 2019, 17, e00575. [CrossRef]

35. Lovelock, C.E.; Sorrell, B.K.; Hancock, N.; Hua, Q.; Swales, A. Mangrove forest and soil development on a rapidly accreting shore in New Zealand. Ecosystems 2010, 13, 437-451. [CrossRef]

36. Lunstrum, A.; Chen, L. Soil carbon stocks and accumulation in young mangrove forests. Soil Biol. Biochem. 2014, 75, 223-232. [CrossRef]

37. Marchand, C.; Lallier-Vergès, E.; Baltzer, F. The composition of sedimentaryorganic matter in relation to the dynamic features of a mangrove-fringed coast in French Guiana. Estuar. Coast. Shelf Sci. 2003, 56, 119-130. [CrossRef]

38. Marchand, C.; Lallier-Vergès, E.; Disnar, J.R.; Kéravis, D. Organic carbon sources and transformations in mangrove sediments: A rock-eval pyrolysis approach. Org. Geochem. 2008, 39, 408-421. [CrossRef]

39. Bouillon, S.; Dahdouh-Guebas, F.; Rao, A.V.V.S.; Koedam, N.; Dehairs, F. Sources of organic carbon in mangrove sediments: Variability and possible ecological implications for ecosystem functioning. Hydrobiologia 2003, 495, 33-39. [CrossRef]

40. Barr, J.G.; Fuentes, J.D.; DeLonge, M.S.; O’Halloran, T.L.; Barr, D.; Zieman, J.C. Summertime influences of tidal energy advection on the surface energy balance in a mangrove forest. Biogeosciences 2013, 10, 501-511. [CrossRef]

41. Li, S.B.; Chen, P.H.; Huang, J.S.; Hsueh, M.L.; Hsieh, L.Y.; Lee, C.L.; Lin, H.J. Factors regulating carbon sinks in mangrove ecosystems. Glob. Chang. Biol. 2018, 24, 4195-4210. [CrossRef] [PubMed]

42. Chen, L.; Mu, X.; Yuan, Z.; Deng, Q.; Chen, Y.; Yuan, L.Y.; Ryan, L.T.; Kallenbach, R.L. Soil nutrients and water affect the age-related fine root biomass but not production in two plantation forests on the Loess Plateau, China. J. Arid Environ. 2016, 135, 173-180. [CrossRef]

43. Matsui, N.; Meepol, W.; Chukwamdee, J. Soil organic carbon in mangrove ecosystems with different vegetation and sedimentological conditions. J. Mar. Sci. Eng. 2015, 3, 1404-1424. [CrossRef]

44. Mcleod, E.; Chmura, G.L.; Bouillon, S.; Salm, R.; Bjork, M.; Duarte, C.M.; Lovelock, C.E.; Schlesinger, W.H.; Silliman, B.R. A blueprint for blue carbon: Toward an improved understanding of the role of vegetated coastal habitats in sequestering $\mathrm{CO}_{2}$. Front. Ecol. Environ. 2011, 9, 552-560. [CrossRef]

45. Hutchison, J.; Manica, A.; Swetnam, R.; Balmford, A.; Spalding, M. Predicting global patterns in mangrove forest biomass. Conserv. Lett. 2014, 7, 233-240. [CrossRef]

(C) 2020 by the authors. Licensee MDPI, Basel, Switzerland. This article is an open access article distributed under the terms and conditions of the Creative Commons Attribution (CC BY) license (http://creativecommons.org/licenses/by/4.0/). 